\title{
Estimating the size of a methane emission point source at different scales: from local to landscape
}

\author{
Stuart N. Riddick ${ }^{1, \mathrm{a}}$, Sarah Connors ${ }^{1}$, Andrew D. Robinson ${ }^{1}$, Alistair J. Manning ${ }^{2}$, Pippa S. D. Jones ${ }^{1}$, David Lowry $^{3}$, \\ Euan Nisbet $^{3}$, Robert L. Skelton ${ }^{4}$, Grant Allen ${ }^{5}$, Joseph Pitt ${ }^{5}$, and Neil R. P. Harris ${ }^{6}$ \\ ${ }^{1}$ Centre for Atmospheric Science, University of Cambridge, Cambridge CB2 1EZ, UK \\ ${ }^{2}$ Met Office, Exeter EX1 3PB, UK \\ ${ }^{3}$ Department of Earth Sciences, Royal Holloway, University of London, Egham TW20 0EX, UK \\ ${ }^{4}$ Department of Chemical Engineering, University of Cambridge, Cambridge CB2 3RA, UK \\ ${ }^{5}$ Centre for Atmospheric Science, University of Manchester, Manchester M13 9PL, UK \\ ${ }^{6}$ Centre for Atmospheric Informatics and Emissions Technology, Cranfield University, Cranfield MK43 0AL, UK \\ ${ }^{a}$ now at: Department of Civil and Environmental Engineering, Princeton University, Princeton, 08544, USA
}

Correspondence to: Stuart N. Riddick (sriddick@princeton.edu) and Neil R. P. Harris (neil.harris@cranfield.ac.uk)

Received: 28 October 2016 - Discussion started: 22 November 2016

Revised: 10 April 2017 - Accepted: 12 April 2017 - Published: 29 June 2017

\begin{abstract}
High methane $\left(\mathrm{CH}_{4}\right)$ mixing ratios (up to $4 \mathrm{ppm}$ ) have occurred sporadically at our measurement site in Haddenham, Cambridgeshire, since July 2012. Isotopic measurements and back trajectories show that the source is the Waterbeach Waste Management Park $7 \mathrm{~km}$ SE of Haddenham. To investigate this further, measurements were made on 30 June and 1 July 2015 at other locations nearer to the source. Landfill emissions have been estimated using three different approaches at different scales; near source using the WindTrax inversion dispersion model, middle distance using a Gaussian plume (GP) model and at the landscape scale using the Numerical Atmospheric Modelling Environment (NAME) Inversion Technique for Emission Modelling (InTEM) inversion. The emission estimates derived using the WindTrax and Gaussian plume (GP) approaches agree well for the period of intense observations. Applying the Gaussian plume approach to all periods of elevated measurements seen at Haddenham produces year-round and monthly landfill emission estimates with an estimated annual emission of $11.6 \mathrm{Gg} \mathrm{CH}_{4} \mathrm{yr}^{-1}$. The monthly emission estimates are highest in winter ( $2160 \mathrm{~kg} \mathrm{~h}^{-1}$ in February) and lowest in summer $\left(620 \mathrm{~kg} \mathrm{~h}^{-1}\right.$ in July). These data identify the effects of environmental conditions on landfill $\mathrm{CH}_{4}$ production and highlight the importance of year-round measurements to capture seasonal variability in $\mathrm{CH}_{4}$ emission.
\end{abstract}

\section{Introduction}

Atmospheric methane $\left(\mathrm{CH}_{4}\right)$ gas is both a greenhouse gas and partially responsible for modulating tropospheric ozone production and loss. As such, changes in atmospheric $\mathrm{CH}_{4}$ mixing ratios can cause significant shifts in local and regional atmospheric chemistry and global climate. Current research suggests the most significant $\mathrm{CH}_{4}$ sources are natural wetlands (top-down, 142-208 $\mathrm{Tg} \mathrm{CH}_{4} \mathrm{yr}^{-1}$; and bottom-up, 177-284 $\mathrm{Tg} \mathrm{CH}_{4} \mathrm{yr}^{-1}$ ) and agriculture and waste emissions (top-down, 180-241 $\mathrm{Tg} \mathrm{CH}_{4} \mathrm{yr}^{-1}$; and bottom-up, 187-224 $\mathrm{Tg} \mathrm{CH}_{4} \mathrm{yr}^{-1}$ ), with further contributions from fugitive emission due to the use of fossil fuels, natural emissions and biomass burning (IPCC, 2013; Kirschke et al., 2013). Anthropogenic sources contribute $\sim 60 \%$ of modernday emissions (Saunois et al., 2016). Included in these estimates, decomposition of organic matter at landfills is estimated to comprise between 3 and $19 \%$ of global anthropogenic emissions (Chen and Prinn, 2006). Given this large and important uncertainty, the aim of this study is to estimate $\mathrm{CH}_{4}$ mass flux from an operational landfill in Cambridgeshire using a variety of methods.

Approximately $60 \%$ of gas emitted from typical landfills is $\mathrm{CH}_{4}, 40 \%$ is carbon dioxide, and trace amounts are given off as nitrogen, oxygen and water vapour (Hegde et al., 2003). At the surface, anoxic microbial processes form 
$\mathrm{CH}_{4}$, whereas oxidation forms both carbon dioxide and water. Deeper below the surface anaerobic processes dictate gas formation due to the oxygen-poor environment. Simple organic acids (e.g. carboxylic acid), carbon dioxide $\left(\mathrm{CO}_{2}\right)$ and hydrogen $\left(\mathrm{H}_{2}\right)$ are formed from the hydrolysis of organic matter. Methanogenic bacteria then convert carboxylic acid ( $\mathrm{RCOOH}$ ) to $\mathrm{CH}_{4}$, which can diffuse through the refuse to be emitted to the atmosphere (Xu et al., 2014). Riddick et al. (2016) suggest that instead of heterogeneous emission across the landscape landfill, $\mathrm{CH}_{4}$ is emitted in discrete hotspots which may be caused by variability in the materials that can degrade to form $\mathrm{CH}_{4}$ throughout the landfill and the nature of physical transmission pathways to the surface. Modern landfills in the UK have extensive reticulations of gas pipes to extract methane, and fractures or leaks in the pipes create potent point sources of methane to escape past the soil oxidation barrier.

The emitted $\mathrm{CH}_{4}$ can be identified by measuring its $\delta^{13} \mathrm{C}$ isotopic signature. Typically, biogenic methane has a $\delta^{13} \mathrm{C}$ isotopic signature of between -55 and $-70 \%$ (Dlugokencky et al., 2011). However, landfill methane emissions, which comprise the residual gas after the methane flux has passed through the oxidation barrier in the soil cover, tend to fall at the isotopically heavier end of this range as oxidative methanotrophy is selective for the lighter carbon. Typically, the $\delta^{13} \mathrm{C}$ isotopic signature for landfill $\mathrm{CH}_{4}$ in the south-east of the UK has been measured at $-58 \pm 3 \%$ o (Zazzeri et al., 2015).

Although landfill interiors are well isolated from day-today weather, and even seasonality, emissions from the landfill surface can be strongly affected by environmental conditions. Xu et al. (2012) and Riddick et al. (2016) observed decreasing landfill $\mathrm{CH}_{4}$ emission as surface atmospheric pressure increased at landfill sites in Lincoln, USA, and Ipswich, UK, respectively. Emission of landfill $\mathrm{CH}_{4}$ may be suppressed as atmospheric pressure increases; conversely, the passage of depressions may pneumatically draw gas out from the landfill. Landfill $\mathrm{CH}_{4}$ emissions decrease with increased ground temperature in dry soil conditions (Scheutz et al., 2004; Riddick et al., 2016). This is consistent with the hypothesis that bacterial methanotrophic oxidation of methane in the aerobic cover soil has an Arrhenius relationship with temperature, increasing exponentially with ground temperature between 2 and $25^{\circ} \mathrm{C}$ (Maurice and Lagerkvist, 2004; Scheutz and Kjeldsen, 2004).

A variety of methods have been used to estimate $\mathrm{CH}_{4}$ emission estimates from landfill sites using on-site and nearsite measurements. These include chamber methods, tracer plume and eddy covariance. Tracer release methods have been used to good effect, where pollutant mixing ratios are estimated using the co-release of a tracer at a known rate. However, this methodology needs the spatial distribution of tracer emissions to be configured so that it approximately matches the landfill $\mathrm{CH}_{4}$ emissions (Mønster et al., 2014), presenting logistical challenges when operating on active landfill sites. Landfill $\mathrm{CH}_{4}$ emissions have been measured using eddy covariance techniques, which use the covariance between vertical wind speed and gas mixing ratio to estimate emissions at a high sampling rate (Xu et al., 2012). However, the assumption of homogeneity by eddy covariance calculations is invalidated by the heterogeneous nature of landfill $\mathrm{CH}_{4}$ emissions. Furthermore, these estimates strictly apply to the area and time where the measurements are made. Estimates produced in a heterogeneous environment such as a landfill can thus be hard to interpret or extrapolate to the whole landfill and to other times of year.

Riddick et al. (2016) treated a landfill site in Suffolk, $\mathrm{UK}$, as a point source and estimated a mean $\mathrm{CH}_{4}$ emission of $709 \mu \mathrm{g} \mathrm{m}^{-2} \mathrm{~s}^{-1}$ using $\mathrm{CH}_{4}$ concentration data, collected $800 \mathrm{~m}$ from the landfill, and meteorological data in an inverse dispersion model. At a farther distance, $2 \mathrm{~km}$, Hensen and Scharff (2001) used a Gaussian plume model to estimate emissions of between 66 and $292 \mu \mathrm{g} \mathrm{m}^{-2} \mathrm{~s}^{-1}$ from three landfill sites near Amsterdam in the Netherlands. To our knowledge no research has been conducted on using a Gaussian plume approach at more than $2 \mathrm{~km}$. Additionally, we believe that no other study has attempted to use an inversion model to identify emission hotspots within a landscape

In this study we use methane measurements made at Haddenham, Cambridgeshire, in which we record intermittently high values of up to $4 \mathrm{ppm}$ when the wind is from the southeast. Methane emissions from the Waterbeach landfill site, $7 \mathrm{~km}$ to the SE of our measurement site at Haddenham, are a likely source of these enhancements. To aid identification of this $\mathrm{CH}_{4}$ source, we collected air samples during a south-easterly air flow and measured the relative abundance of $\delta^{13} \mathrm{C}$ isotopes. These are compared with additional measurements made nearer the landfill. Short time series of $\mathrm{CH}_{4}$ measurements taken near the landfill are used to estimate emissions using the inverse dispersion model WindTrax (www.thunderbeachscientific.com). The emissions are compared with a Gaussian plume estimate made using the Haddenham data for the same period. The Gaussian plume calculations are extended to cover the whole of the first 2 years of measurements at Haddenham in order to investigate how the emissions vary over time. Finally, we aim to compare the annual emission estimate found using the Gaussian model with the estimate from the Numerical Atmospheric Modelling Environment (NAME) Inversion Technique for Emission Modelling (InTEM) inversion model that uses 2 years of $\mathrm{CH}_{4}$ measurement data from a network throughout East Anglia to estimate the regional annual emission.

The measurement and modelling techniques used are described in Sect. 2. The modelling studies performed are described in Sect. 3. The results are then presented in Sect. 4. The paper concludes with a short discussion and the conclusions of the results and the broader applicability of the approach. 


\section{Methods}

This paper presents methane emission estimates from a landfill made by three methods at different scales: near source, middle distance and landscape; a summary of each method is presented in Table 1. The Waterbeach Waste Management Park $\left(52.302^{\circ} \mathrm{N}, 0.180^{\circ} \mathrm{E}\right)$ is used to deposit unrecyclable waste on an open active area approximately $700 \mathrm{~m}$ by $300 \mathrm{~m}$. Surrounding the active area is an area of decomposing waste capped with a welded high-density polyethylene geomembrane and covered with at least $2 \mathrm{~m}$ of top soil. Landfill gas is extracted from this capped area under suction using a network of pipes and wells and is used as fuel for the on-site electricity generators. The various measurement techniques are now described in turn.

\subsection{Isotopic methane measurements}

Whole air samples were collected in $3 \mathrm{~L}$ Teflon bags at Haddenham church (Fig. 1). These samples were taken over 11 February 2015 when the wind was from the south/southeast, i.e. from the direction of the landfill. Air samples were taken at Haddenham in the early morning in order to capture the elevated mixing ratio of landfill emissions within the nocturnal boundary layer. The carbon isotopic ratio, expressed in $\%$, was measured in triplicate to high precision $( \pm 0.05 \%$ o by continuous-flow gas chromatography isotope ratio mass spectrometry (Fisher et al., 2006) at Royal Holloway, University of London (RHUL).

\subsection{Near source}

\subsubsection{Measurements - Los Gatos UGGA}

The Los Gatos Research Ultraportable Greenhouse Gas Analyzer (UGGA; www.lgrinc.com) is a laser absorption spectrometer that measures $\mathrm{CH}_{4}$ and $\mathrm{CO}_{2}$ concentration in air using off-axis integrated cavity output spectroscopy (Paul et al., 2001). The UGGA reports $\mathrm{CO}_{2}$ mixing ratio and $\mathrm{CH}_{4}$ mixing ratio every second, with a stated precision of $<2 \mathrm{ppb}(1 \sigma$ @ $1 \mathrm{~Hz}$ ) over an operating range of 0.1 to $100 \mathrm{ppm}$. Calibration of the UGGA was done before and after deployment using low (1.93 ppm), target (2.03 ppm) and high (2.74 ppm) gases calibrated on the WMO (World Meteorological Organization) scale.

The UGGA was deployed on a farm road on Mitchell Hill Farm, Cottenham $\left(52.304^{\circ} \mathrm{N}, 0.170^{\circ} \mathrm{E}\right)$, where it measured the mixing ratio of $\mathrm{CH}_{4}$ downwind of the landfill. The measurement site was $300 \mathrm{~m} \mathrm{NW}$ of the landfill site. The inlet line was attached to a mast $2.5 \mathrm{~m}$ above the ground, protected from water incursion using an aluminium funnel and filtered using a $2 \mu \mathrm{m}$ filter. A $15 \mathrm{~min}$ averaged background methane concentration was measured background $\mathrm{CH}_{4}$ mixing ratios were measured using the Los Gatos UGGA downwind of the landfill site before, at $12 \mathrm{pm}$ and after each day's measurements.

\subsubsection{Meteorological data}

In situ meteorological data were collected using a wireless weather station (Maplin, UK) attached to a mast at $2 \mathrm{~m}$ from the ground at the measurement site on Mitchell Hill Farm. Meteorological data were sampled and recorded at $5 \mathrm{~min}$ intervals and include wind speed $\left(u, \mathrm{~m} \mathrm{~s}^{-1}\right)$, wind direction (WD, ${ }^{\circ}$ to north), air temperature at $2 \mathrm{~m}\left(T_{\mathrm{a}}, \mathrm{K}\right)$, relative humidity $(\mathrm{RH}, \%)$, rain rate $\left(R, \mathrm{~mm} \mathrm{~h}^{-1}\right)$ and air pressure $(P$, $\mathrm{Pa})$.

Micrometeorological parameters used for subsequent modelling were calculated from data collected at the same measurement site on Mitchell Hill Farm. Roughness height $\left(z_{0}, \mathrm{~m}\right)$ and Monin-Obukhov length $(L, \mathrm{~m})$ are calculated from the wind speeds measured at three heights. The roughness length is calculated as the exponential of the intercept, with the natural logarithm of wind measurement heights plotted against wind speeds. The Monin-Obukhov length is calculated (Eq. 1) from the density of air $\left(\rho, \mathrm{kg} \mathrm{m}^{-3}\right)$, the specific heat capacity of air at constant pressure $\left(c_{p}\right.$, $\left.\mathrm{J} \mathrm{kg}^{-1} \mathrm{~K}^{-1}\right)$, the absolute temperature of air at $z=0\left(T_{0}, \mathrm{~K}\right)$, the acceleration due to gravity $\left(g, \mathrm{~m} \mathrm{~s}^{-1}\right)$ and the sensible heat flux $\left(H, \mathrm{~W} \mathrm{~m}^{-2}\right)$. The sensible heat flux $\left(H, \mathrm{~W} \mathrm{~m}^{-2}\right)$ is calculated (Eq. 2) from the transfer coefficient for heat flux $\left(\mathrm{CH}, 1 \times 10^{-3}\right.$; Pan et al., 2004).

$L=-\frac{\rho c_{p} T_{0} u_{*}^{3}}{K g H}$
$H=\rho c_{p} \mathrm{CH}\left(T_{\mathrm{a}}-T_{0}\right) u$

\subsubsection{Model used - WindTrax inverse dispersion model}

The inversion function of the WindTrax atmospheric dispersion model version 2.0 (Flesch et al., 1995) is used to infer the $\mathrm{CH}_{4}$ emissions from the landfill. Methane emissions are calculated using measured $\mathrm{CH}_{4}$ mixing ratios downwind, measured background $\mathrm{CH}_{4}$ mixing ratios upwind and the simulated ratio of $\mathrm{CH}_{4}$ mixing ratio enhancement to emission (Flesch et al., 2004, 2005). WindTrax calculates the ratio of the $\mathrm{CH}_{4}$ mixing ratio to emission by back-calculating the movement of many $\mathrm{CH}_{4}$ particles from the detector to the landfill emission area and estimating the vertical velocity as they leave the emission area. Following the method of Laubach et al. (2008) and Flesch et al. (2009), $\mathrm{CH}_{4}$ mixing ratios and meteorological data were averaged over $15 \mathrm{~min}$ to preserve real changes to $\mathrm{CH}_{4}$ emission caused by changing environmental or atmospheric factors. Each $15 \mathrm{~min}$ averaged measurement is used as an input to back-calculate the $\mathrm{CH}_{4}$ emission using 50000 particle trajectories.

\subsection{Middle distance}

\subsubsection{Measurements - GC-FID}

Methane mixing ratios were measured every $75 \mathrm{~s}$ from July 2012 to July 2015 at the Holy Trinity church, Hadden- 


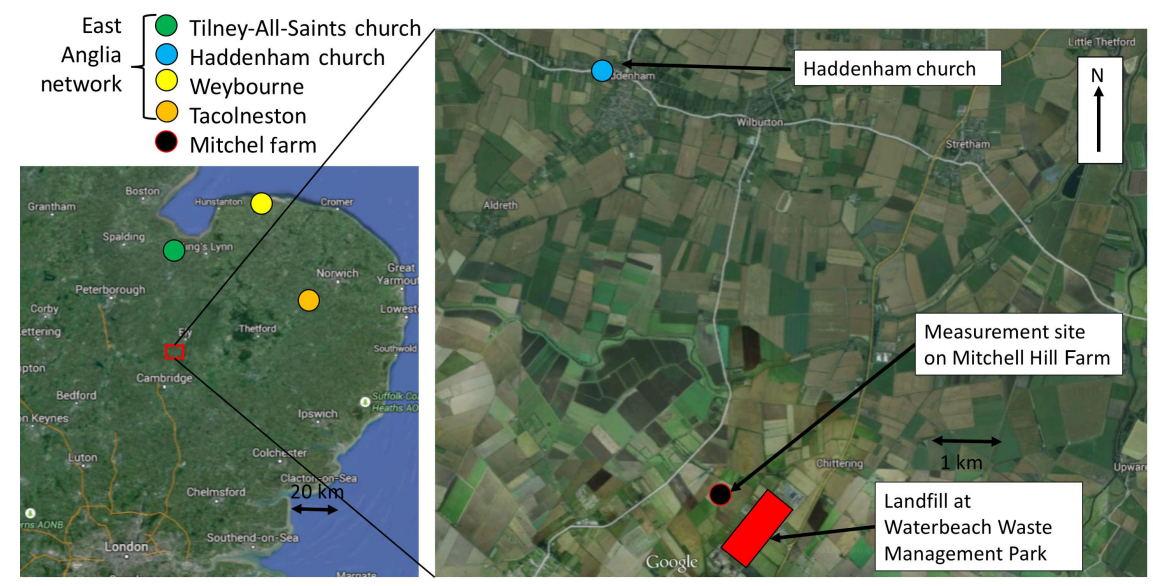

Figure 1. Location of the East Anglia measurement network (Tilney-All-Saints church, Haddenham church, Weybourne and Tacolneston), landfill at the Waterbeach Waste Management Park and the measurement site at Mitchell Hill Farm, Cambridgeshire. The map was retrieved on 23 July 2015 (Google Earth, 2015).

ham $\left(52.359^{\circ} \mathrm{N}, 0.148^{\circ} \mathrm{E}\right)$, since July 2012 (see Fig. 1) using a 200 Series Ellutia GC-FID (gas chromatography with a flame ionization detector; www.ellutia.com). The site elevation is $40 \mathrm{~m}$ above sea level and the inlet is on the tower, $25 \mathrm{~m}$ above the ground. The GC-FID takes air to be assayed for $\mathrm{CH}_{4}$ mixing ratio mixed with a carrier gas which passes through a column of alumina-coated tubing heated in an oven at $90^{\circ} \mathrm{C}$. As the gases exit the column they are pyrolysed by a hydrogen-air mixture within the flame ionization detector. Ions formed during the combustion are measured to indicate the mixing ratio of the gas species. The Ellutia GC-FID, as used here, has a detection limit of approximately $1.5 \mathrm{ppb}$, a range of 1.5 to $3 \mathrm{ppm}$ and measures mixing ratios every $75 \mathrm{~s}$. The instrument is calibrated every 30 min using a gas standard. The Teflon inlet line is attached to the church roof $30 \mathrm{~m}$ above the ground and is protected from water incursion using an aluminium funnel and a $2 \mu \mathrm{m}$ particle filter.

The data are transmitted back to the laboratory for processing. Data processing of individual chromatograms is done using IGOR Pro (Wavemetrics, USA) to determine peak height. Measurements from all sites are calibrated to the WMO calibration scale (Dlugokencky et al., 2005). Hourly WMOcalibrated mixing ratios are then calculated using Openair in $\mathrm{R}$.

\subsubsection{Meteorological data}

Data were taken from UK Met Office's Numerical Atmospheric Modelling Environment model, as described later in Sect. 2.4.2.

\subsubsection{Model used - Gaussian plume}

The Gaussian plume model describes the mixing ratio of a gas as a function of distance downwind from a point source (Seinfeld and Pandis, 2006). The particle trajectories were calculated in the NAME model and could have been used the calculate emissions; however, given the short distance from the landfill to the monitoring station and the availability of observed meteorology, it was decided that a Gaussian plume model would be better suited for our purposes. As a gas is emitted, it is entrained in the prevailing ambient air flow and disperses in the $y$ and $z$ directions (relative to a mean horizontal flow in the $x$ direction) with time, forming a cone. The gas is considered to be well mixed within the volume of the cone, such that the mixing ratio of the gas as a function of distance downwind depends on the emission flux at source, the advective wind speed $\left(u, \mathrm{~m} \mathrm{~s}^{-1}\right)$ and the rate of dispersion (governed by boundary layer micrometeorological factors described in Sect. 2.2). The mixing ratio of the gas $\left(X, \mu \mathrm{g} \mathrm{m}^{-3}\right)$, at any point $x$ metres downwind of the source, $y$ metres laterally from the centre line of the plume and $z$ metres above ground level, can be calculated (Eq. 3) using the source strength $\left(Q, \mathrm{~g} \mathrm{~s}^{-1}\right)$, the height of the source $\left(h_{\mathrm{s}}\right.$, $\mathrm{m})$ and the air stability. The standard deviations of the lateral $\left(\sigma_{y}, \mathrm{~m}\right)$ and vertical $\left(\sigma_{z}, \mathrm{~m}\right)$ mixing ratio distributions are calculated from the stability class of the air; the values used in our analyses are presented in Supplement Sect. S1 (Pasquill, 1974). The Gaussian plume approach assumes that the vertical eddy diffusivity and wind speed are constant and that there is total reflection of methane at the surface (e.g. Zannetti, 1990; Hensen and Scharff, 2001; Hensen et al., 2009).

Concentration $(x, y, z)=$

$$
\frac{Q}{2 \pi u \sigma_{y} \sigma_{z}} e^{-\frac{y^{2}}{\left(2 \sigma_{y}\right)^{2}}}\left(e^{-\frac{\left(z-h_{s}\right)^{2}}{\left(2 \sigma_{z}\right)^{2}}}+e^{-\frac{\left(z+h_{s}\right)^{2}}{\left(2 \sigma_{z}\right)^{2}}}\right)
$$




\subsection{Landscape}

\subsubsection{Measurements - East Anglia network}

Methane mixing rations were measured by a network of four sites throughout East Anglia: Tilney-All-Saints church, Haddenham church, Weybourne and Tacolneston (Fig. 1). Ellutia GC-FIDs, as described in Sect. 2.3.1, were used at Tilney-All-Saints church, Haddenham church and Weybourne. Measurement at Haddenham church is described in Sect. 2.3.1; similar systems were arranged at Tilney-AllSaints and Weybourne, where inlet were positioned at 25 and $15 \mathrm{~m}$ from the ground, respectively. A Picarro CRDS (cavity ring-down spectrometer) measured the $\mathrm{CH}_{4}$ mixing ratios in air at Tacolneston at 50 and $100 \mathrm{~m}$ from the ground. Calibration of the Picarro CRDS was done daily for $10 \mathrm{~min}$ using low (1.93 ppm), target (2.03 ppm) and high (2.74 ppm) $\mathrm{CH}_{4}$ gases calibrated using the World Meteorological Organization scale.

\subsubsection{Model used - InTEM inversion modelling}

The dispersion model used to represent air flow from potential methane sources to the measurement site is the UK Met Office's Numerical Atmospheric Modelling Environment (NAME) model (Jones et al., 2007). This is a Lagrangian dispersion model which runs using 3-D meteorological fields produced by the UK Met Office's numerical weather prediction model, the Unified Model (UM; Cullen, 1993). These meteorological fields are available on two resolutions: global (3 hourly, $25 \mathrm{~km}$ ) and UK (hourly, $1.5 \mathrm{~km}$ ). NAME was run using a combination of both resolutions with the $1.5 \mathrm{~km}$ UK fields nested within the global data.

NAME produces a modelled representation of the contributing surface influence (defined as the $100 \mathrm{~m}$ above ground level in NAME) to a particular source location over a defined period of time. This is done by releasing chemically inert particles $\left(10000 \mathrm{~h}^{-1}\right)$ from the $x, y, z$ coordinate of a measurement site location. Their movements and geolocation are tracked backwards in time every minute for 5 days. NAME produces a time-integrated particle density map for each source (units $\mathrm{g} \mathrm{s} \mathrm{m}^{-3}$ ), which shows, on a gridded output, what relative contribution each grid square has had over the 5-day period (Manning et al., 2011). The resolution of this air history map is equal to $1.5 \times 1.5 \mathrm{~km}$.

Emissions are inferred in InTEM by using an iterative best-fit technique, simulated annealing, which compares the hourly measured observations with derived modelled observations, based on the NAME InTEM method described in Manning (2003) and Manning et al. (2011). These modelled, or "pseudo", observations are created by multiplying a simulated emissions field $\left(\mathrm{g} \mathrm{s}^{-1} \mathrm{~m}^{-3}\right)$ with a representation of the physical atmospheric processes for each measurement (Eq. 4).

$$
\begin{aligned}
& \text { emissions }\left(\mathrm{g} \mathrm{s}^{-1} \mathrm{~m}^{-2}\right) \times \text { dilution }\left(\mathrm{s} \mathrm{m}^{-1}\right) \\
& =\text { concentration }\left(\mathrm{g} \mathrm{m}^{-3}\right)
\end{aligned}
$$

The dilution matrix (units $\mathrm{s} \mathrm{m}^{-1}$ ), which links the simulated emission field $\left(\mathrm{g} \mathrm{s} \mathrm{m}^{-3}\right)$ with the observations $\left(\mathrm{g} \mathrm{m}^{-2}\right)$, is produced from the hourly NAME air history maps by dividing by the mass released $(g)$ and then multiplying by a surface area matrix $\left(\mathrm{m}^{2}\right)$. This dilution matrix is multiplied by the InTEM-generated emissions field (both are gridded to the solution grid resolution).

The two observation time series are quantitatively assessed using a "least squares" cost function, shown in Eq. (5). For each time step, the difference between the measured $\left(y_{i}\right)$ and the pseudo-observations $\left((k x)_{i}\right)$ is weighted by the total uncertainty $\left(\left(\sigma_{\epsilon}^{2}\right)_{i}\right)$, where the uncertainty is defined as the total error estimated in measurement observations, modelling and baselines (Connors et al., 2017). This allows for any potential bias due to highly uncertain observations to be accounted for. High $\mathrm{CH}_{4}$ concentration values seen at Haddenham are usually short lived and only appear as peaks lasting a maximum of only a few hours. These usually occur at night time and, as the isotopic analysis shows, probably come from a landfill, which is an intermittent of $\mathrm{CH}_{4}$. These are therefore more uncertain. The values would have a relatively high cost score at these times. So, including an hourly standard deviation into the uncertainty calculation helps to de-weight the large concentrations, which have higher uncertainty, from increasing the overall cost score.

InTEM then iterates for thousands of potential emission fields through the simulated annealing technique to find an optimum result with the lowest cost score (Eq. 5). Uncertainty correlation was not considered in the modelling, and errors are considered independent of each other. This is a weakness, and further analysis is needed using other cost functions (e.g. the Bayesian cost function).

$J(X)=\sum_{i=1}^{m} \frac{\left(y_{i}-(k x)_{i}\right)^{2}}{\left(\sigma_{\epsilon}\right)_{i}^{2}}$

\section{Model runs}

\subsection{Instantaneous methane emissions - summer 2015 case study}

\subsubsection{Near source - inverse dispersion modelling}

The inversion function of the WindTrax atmospheric dispersion model version 2.0 (Flesch et al., 1995) is used to infer the $\mathrm{CH}_{4}$ emissions from the Waterbeach landfill using the mixing ratio data collected at Mitchell Hill Farm on 30 June and 1 July 2015. Data used as input to WindTrax are wind speed $\left(u, \mathrm{~m} \mathrm{~s}^{-1}\right)$, wind direction $\left(\mathrm{WD},{ }^{\circ}\right)$, temperature $(T$, 
$\left.{ }^{\circ} \mathrm{C}\right), \mathrm{CH}_{4}$ mixing ratio at $4 \mathrm{~m}\left(X, \mu \mathrm{g} \mathrm{m}^{-3}\right)$, background $\mathrm{CH}_{4}$ mixing ratio $\left(X_{\mathrm{b}}, \mu \mathrm{g} \mathrm{m}^{-3}\right)$, the Monin-Obukhov length and the surface roughness. The $15 \mathrm{~min}$ averaged $\mathrm{CH}_{4}$ mixing ratio data are screened for erroneous values, and data are removed for any periods where wind did not come from the landfill or for high atmospheric stability events, i.e. wind speed, $u<0.15 \mathrm{~ms}^{-1}$.

An uncertainty analysis is conducted, where potential variant input values are used in rerun WindTrax scenarios to calculate the resultant change in calculated $\mathrm{CH}_{4}$ emission. These uncertainties are then combined as the square root of the sum of the squares of the individual uncertainties to give an overall uncertainty in emission estimate. The main sources of error are the size of the emission area, as it changed daily, wind speed, the roughness length, and the Monin-Obukhov length. The values used to estimate the uncertainty are from published data.

\subsubsection{Emissions from middle distance - Gaussian plume model}

A Gaussian plume approach, was used to infer the $\mathrm{CH}_{4}$ emissions from the Waterbeach landfill using the mixing ratio data collected at Haddenham church on 30 June and 1 July 2015. Data used as input to the GP model are wind speed, wind direction, temperature, $\mathrm{CH}_{4}$ mixing ratio at $4 \mathrm{~m}$, background $\mathrm{CH}_{4}$ mixing ratio and the Pasquill-Gifford atmospheric stability class. The Pasquill-Gifford stability classes are estimated from calculated values of the Monin-Obukhov length as measured at Mitchell Hill Farm. As with the inverse dispersion modelling approach, $15 \mathrm{~min}$ averaged data are used and screened for erroneous values, any periods where the prevailing wind did not come from the direction of the landfill or for high atmospheric stability events.

The main uncertainty using the GP approach is in estimating the Pasquill-Gifford atmospheric stability class. The Monin-Obukhov length is used to assign this value, and an uncertainty of $\pm 7 \%$ was used here because $L$ is calculated using two anemometers, each with $5 \%$ uncertainty. Other sources of uncertainty were in the instruments used to measure $\mathrm{CH}_{4}$ mixing ratio and temperature, with uncertainty ranges discussed in Sect. 2. In addition to these sources, a potentially important, yet unquantifiable, uncertainty could be off-site sources of emission; unlike the inverse dispersion approach, the GP used in the configuration assumes the landfill is the only point-source emitter situated $6 \mathrm{~km}$ to the southeast of the measurement location and does not take into account other nearby sources, such as emissions from the onsite generator or other sources upwind. However, any significant difference between the emission estimates calculated using the inversion and the GP approaches may usefully serve to indicate the size of emission from the rest of the Waterbeach Waste Management Park and beyond.

\subsection{Annual and seasonal emission estimates}

\subsubsection{Middle distance - Gaussian plume model}

The GP approach is described above. Data used as input to GP model are wind speed, wind direction, temperature, $\mathrm{CH}_{4}$ mixing ratio, background $\mathrm{CH}_{4}$ mixing ratio and the Pasquill atmospheric stability class. Hourly data are used and screened for erroneous values, any periods where wind did not come from the landfill or for high atmospheric stability events.

As with the case study in Sect. 3.1.1, the main source of error used as input for the GP approach is the size of the uncertainty in estimating the Pasquill-Gifford atmospheric stability class. The study also includes the instrument precision and wind speed and temperature uncertainties as derived from the NAME model. Additionally, we assume the landfill is the only point-source emitter $6 \mathrm{~km}$ to the south-east and does not take into account other nearby sources, such as emissions from the on-site generator and further upwind.

\subsubsection{Landscape - InTEM inversion model}

The results presented here are taken from a study developing a method to estimate regional $\mathrm{CH}_{4}$ emissions in East Anglia (Connors et al., 2017). More details on the measurement sites, the inversion setup used for InTEM, the diagnostics used and the emission uncertainties can be found there and in Connors (2015). The main points for the purposes of this paper are summarized below and in the Supplement Sect. S2.

InTEM was run using data from all four measurement sites (Fig. 1) between 1 June 2013 and 31 May 2014. Repeating the inversion method gives slightly different cost scores and emission totals due to the stochastic nature of the changes made during the simulated annealing process (Manning et al., 2011). For this study, InTEM was repeated 25 times, with this resulting in consistent methane emission estimates, standard deviations and cost score.

Methane emissions are produced on a solution grid of varying spatial resolution. This resolution is determined using the NAME air history maps and the National Atmospheric Emissions Inventory (NAEI) for methane. Surface regions which have a larger influence on the observation sites and have a large emission in the NAEI produce boxes at a higher spatial resolution. The smallest resolution allowed for the emission grid is set equal to the NAME grid resolution $(1.5 \times 1.5 \mathrm{~km})$. The box which contains the Cottenham landfill site is roughly $9 \times 4.5 \mathrm{~km}$.

An estimated methane baseline mixing ratio is calculated to represent the methane mixing ratio that would have been measured at a given site in the absence of emissions from within the dispersion domain. A statistical filtering technique separated methane mixing ratios at each site into eight time series using the NAME air history maps by wind direction. A rolling 18th percentile spanning 1 week is then 


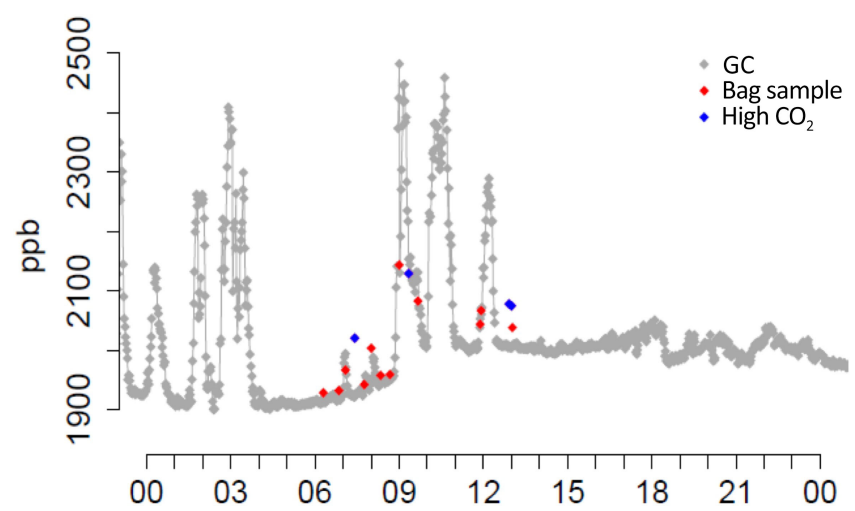

Figure 2. Methane mixing ratios measured by the GC-FID in Haddenham church on 11 February 2015 are presented in grey. Matching methane mixing ratios collected in Tedlar bags on 11 February 21015 and analysed on the 20 February 2015 using a Picarro CRDS at Royal Holloway, University of London, are presented as red points.

passed through each time series. Sensitivity analysis shows this baseline produces emission results with consistently stable emissions with the lowest cost score of all baselines tested. This percentile was chosen as a result of a sensitivity analysis which showed that InTEM inversion results using the 18th percentile produced the lowest cost scores, i.e. the calculated emissions are closer to the measured observations compared to any of the other percentiles tested (percentiles from the 5 th to the 45 th were tested).

The uncertainty estimates used within InTEM reflect the variability of the resulting emission estimates. Uncertainty is defined as the total of the calibration gas uncertainty range, the GC instrument precision, and the standard deviation within the hourly observation, plus a default mixing ratio of $5 \mathrm{ppb}$ to represent uncertainty with the baseline and dispersion modelling. For a more detailed description of the measurement sites and the InTEM setup please refer to Connors et al. (2017).

\section{Results}

\subsection{Isotopic methane measurements}

Several large $\mathrm{CH}_{4}$ plumes were measured by the GC-FID in Haddenham church on 11 February 2015 (Fig. 2) during a wind event from the south-east ranging from background, ca. $1900 \mathrm{ppb}$, to a maximum mixing ratio of $2460 \mathrm{ppb}$. Air samples collected in Tedlar bags at the same time and at the same location and analysed later for $\mathrm{CH}_{4}$ mixing ratio using a Picarro CRDS at RHUL show good agreement in measurement between the GC-FID and Picarro CRDS.

The $\delta^{13} \mathrm{C}$ isotopic signature of the source contributing to excess methane over background can be calculated using the Keeling plot approach (e.g. Zazzeri et al., 2015). This is a

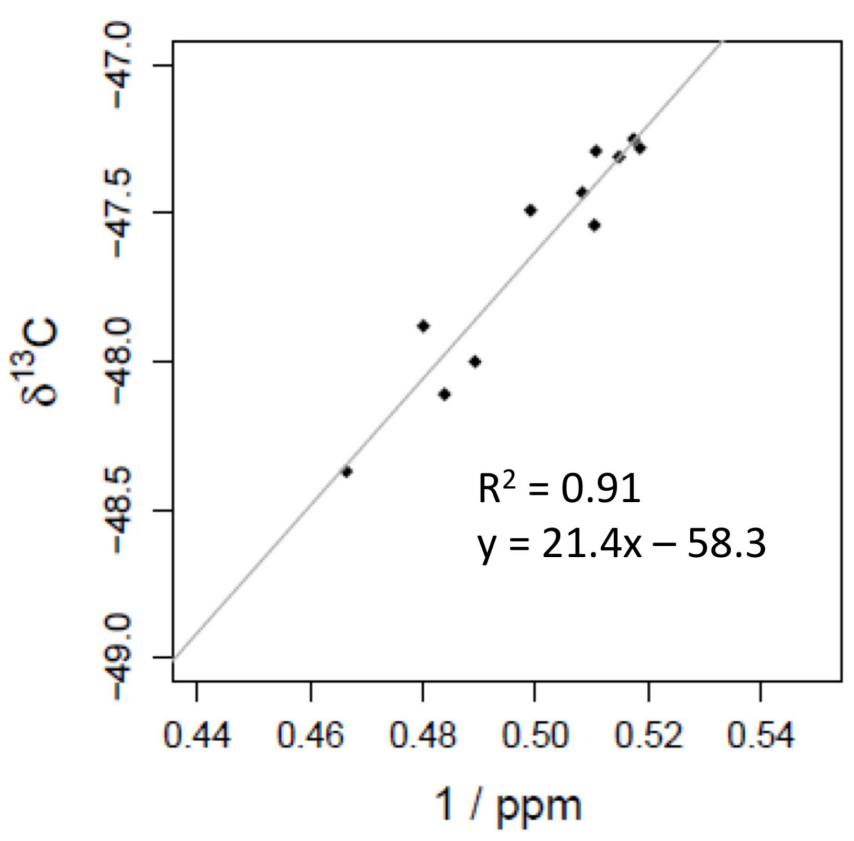

Figure 3. Keeling plot of the air samples taken at Haddenham church between 06:00 and 14:00 UTC on 11 February 2015.

plot of $1 / \mathrm{CH}_{4}$ (ppm) vs. measured isotopic signature for each sample. The intercept of the correlation line fit where $1 / \mathrm{CH}_{4}=\mathrm{O}$ closely approximates the source signature. The Keeling plot of the air samples taken at Haddenham church between 06:00 and 14:00 UTC on 11 February 2015 estimates the $\delta^{13} \mathrm{C}$ isotopic signature at $-58.3 \%$ (Fig. 3). The typical $\delta^{13} \mathrm{C}$ isotopic signature value for a landfill in the south-east of the UK has been estimated to be $-58 \pm 3 \%$ o (Zazzeri et al., 2015), which is very different from other possible local source signatures such as fossil fuels or combustion. This strongly suggests that the air measured at the church has come from a landfill. Air samples were taken closer to the landfill, $10 \mathrm{~m}$ from the active site.

\subsection{Estimating methane emissions - case study June 2015}

The average $\mathrm{CH}_{4}$ emission for the Waterbeach landfill in July based on near-source $\mathrm{CH}_{4}$ measurements used in WindTrax is estimated at $565 \mu \mathrm{g} \mathrm{m}^{-2} \mathrm{~s}^{-1}\left(453 \mathrm{~kg} \mathrm{~h}^{-1}\right)$. In general, emissions on 30 June (average $=256 \mu \mathrm{g} \mathrm{m}^{-2} \mathrm{~s}^{-1}$ ) are ten times lower than those on 1 July (average $\left.=2840 \mu \mathrm{g} \mathrm{m}^{-2} \mathrm{~s}^{-1}\right)$, corresponding to less stable conditions and lower atmospheric pressure on the 1st (Fig. 4). The maximum emission is estimated at $18700 \mu \mathrm{g} \mathrm{m}^{-2} \mathrm{~s}^{-1}$ at 12:15 UTC on 1 July.

A range of scenarios were run in WindTrax to investigate the uncertainty in $\mathrm{CH}_{4}$ emissions caused by the $\mathrm{CH}_{4}$ measurement, the wind speed measurement, estimating the roughness length and estimating the Monin-Obukhov length. 
Table 1. Summary of methods used to calculate methane emission estimates from a landfill at different scales: near source, middle distance and landscape.

\begin{tabular}{|c|c|c|c|c|}
\hline Scale & $\begin{array}{l}\text { Measurement } \\
\text { location (Fig. 1) }\end{array}$ & $\begin{array}{l}\text { Measurement } \\
\text { method }\end{array}$ & $\begin{array}{l}\text { Meteorological } \\
\text { data }\end{array}$ & $\begin{array}{l}\text { Model used to } \\
\text { calculate emission }\end{array}$ \\
\hline Near source & $\begin{array}{l}\text { Mitchell farm, } \\
\text { Cottenham, Cambridgeshire }\end{array}$ & $\begin{array}{l}\text { Los Gatos UGGA } \\
\text { (Sect. 2.2.1) }\end{array}$ & $\begin{array}{l}\text { In situ at Mitchell farm } \\
\text { (Sect. 2.2.2) }\end{array}$ & $\begin{array}{l}\text { WindTrax inverse } \\
\text { model (Sect. 2.2.3) }\end{array}$ \\
\hline Middle distance & $\begin{array}{l}\text { Haddenham church, } \\
\text { Cambridgeshire }\end{array}$ & $\begin{array}{l}\text { Ellutia } 200 \text { Series ) } \\
\text { GC-FID (Sect. 2.3.1) }\end{array}$ & $\begin{array}{l}\text { NAME model runs) } \\
\text { (Sect. 2.4.2) }\end{array}$ & $\begin{array}{l}\text { Gaussian plume } \\
\text { (Sect. 2.3.3) }\end{array}$ \\
\hline Landscape & $\begin{array}{l}\text { East Anglia } \\
\text { measurement network }\end{array}$ & $\begin{array}{l}\text { Ellutia } 200 \text { Series GC-FID (Sect. 2.3.1) } \\
\text { Picarros CRDS (Sect. 2.4.1) }\end{array}$ & $\begin{array}{l}\text { NAME model runs } \\
\text { (Sect. 2.4.2) }\end{array}$ & $\begin{array}{l}\text { InTEM model } \\
\text { (Sect. 2.4.2) }\end{array}$ \\
\hline
\end{tabular}

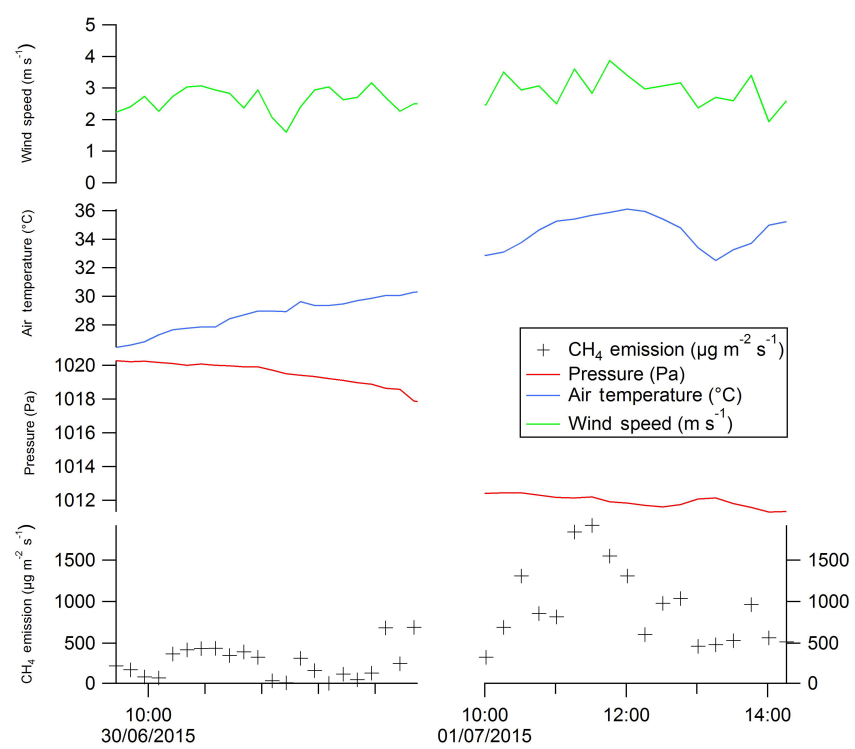

Figure 4. Measured wind speed (top), measured temperature (middle-top), measured pressure (middle-bottom) and methane emission rate as calculated by the WindTrax atmospheric dispersion model (bottom) from data collected at Mitchell Hill Farm, Cottenham, from the landfill at the Waterbeach Waste Management Park on 30 June and 1 July 2015.

Realistic uncertainty in the Monin-Obukhov length and instrument uncertainty for the $\mathrm{CH}_{4}$ measurement have little effect on the emission estimate. Uncertainty in estimating the emission area and roughness length have a noticeable effect on $\mathrm{CH}_{4}$ emission, resulting in an uncertainty of \pm 3 and $\pm 4 \%$ on modelled $\mathrm{CH}_{4}$ emissions, respectively. WindTrax has the greatest response to the uncertainty in estimating wind speed, resulting in an emission uncertainty of $\pm 19 \%$. The overall uncertainty in $\mathrm{CH}_{4}$ emission, calculated as the root of the sum of each component squared, is estimated at $\pm 20 \%$ (Table 2).

The methane emissions calculated using the WindTrax model can be compared with those calculated by a Gaussian plume model using the same measurements. As with WindTrax, the emissions on 30 June (average $=408 \mu \mathrm{g} \mathrm{m}^{-2} \mathrm{~s}^{-1}$ ) are lower than those on 1 July (average $=1270 \mu \mathrm{g} \mathrm{m}^{-2} \mathrm{~s}^{-1}$ ).

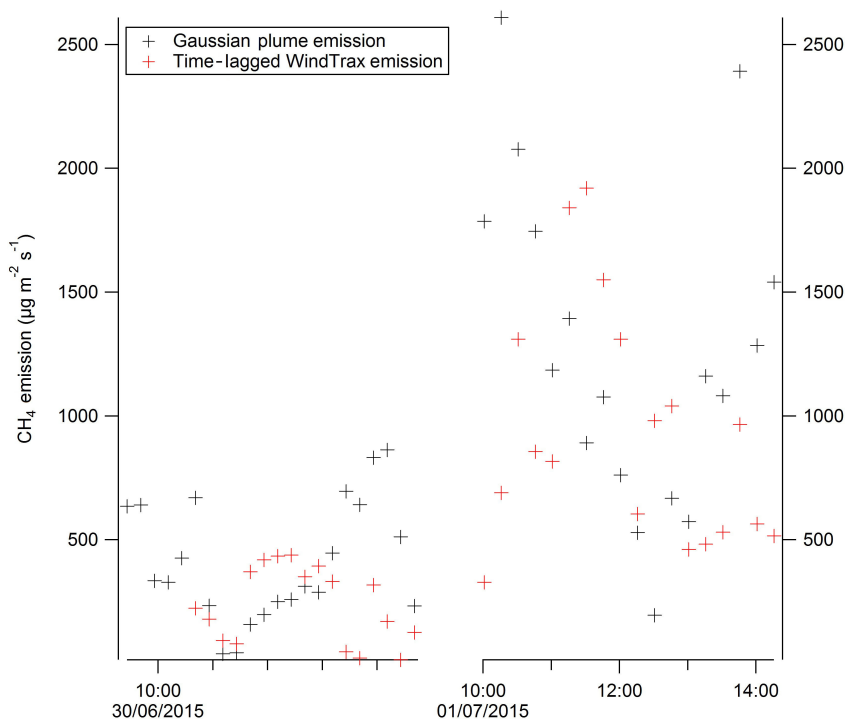

Figure 5. Methane emission rate as calculated by the Gaussian plume modelling approach (black crosses) and the WindTrax atmospheric dispersion model (red crosses) from data collected at Mitchell Hill Farm, Cottenham, from the landfill at the Waterbeach Waste Management Park on 30 June and 1 July 2015.

However, the difference in emissions is not as large (Fig. 5). The maximum emission is estimated at $2590 \mu \mathrm{g} \mathrm{m}^{-2} \mathrm{~s}^{-1}$ at 12:15 UTC on 1 July, which suggests that the Gaussian plume approach measures a more mixed emission than the inversion dispersion model.

A range of scenarios were also configured using the Gaussian plume approach to reflect uncertainty in $\mathrm{CH}_{4}$ measurement, wind speed measurement, temperature measurement and the Monin-Obukhov length (Table 3). Changing the Monin-Obukhov length had no detectable effect on the emission estimate because the change in $L$ is not enough to vary the assigned Pasquill-Gifford stability class use in the emission calculation. Varying the temperature and wind speed had little effect on $\mathrm{CH}_{4}$ emission and resulted in an uncertainty of \pm 1 and $\pm 5 \%$ on modelled $\mathrm{CH}_{4}$ emissions, respectively. The uncertainty in estimating $\mathrm{CH}_{4}$ emissions caused by the instrument precision is the greatest source of uncertainty and results in an uncertainty of the emission estimate of $\pm 22 \%$. 
Table 2. Uncertainty analysis conducted on the case study (June 2015) for methane emission from the landfill at the Waterbeach Waste Management Park as calculated within the WindTrax atmospheric dispersion model.

\begin{tabular}{lrrr}
\hline Variable & Value used & $\begin{array}{r}\text { Average emission } \\
\left(\mu \mathrm{g} \mathrm{m}^{-2} \mathrm{~s}^{-1}\right)\end{array}$ & $\begin{array}{r}\text { Uncertainty } \\
(\%)\end{array}$ \\
\hline Baseline & & 565 & \\
W Monin-Obukhov length & $\pm 7 \%$ & 563 & \pm 0.3 \\
Precision roughness length & $\pm 7 \%$ & 588 & \pm 4 \\
$\mathrm{CH}_{4}$ instrument & $\pm 0.01 \%$ & 567 & \pm 0.3 \\
Wind speed measurement & $\pm 5 \%$ & 671 & \pm 19 \\
Emission area & $\pm 20 \%$ & 547 & \pm 3 \\
\hline & & Total & \pm 20 \\
\hline
\end{tabular}

The overall uncertainty in $\mathrm{CH}_{4}$ emission, calculated as the root of the sum of each component squared, is estimated to be $\pm 23 \%$.

\subsection{Annual and seasonal emission estimates}

Methane emissions from the landfill at the Waterbeach Waste Management Park were calculated using 1171 hourly averaged $\mathrm{CH}_{4}$ mixing ratio data measured at Haddenham church between July 2012 and June 2015. The GP model can only be used to calculate the emission when the wind is blowing from the SE (i.e. from the landfill). For this particular time series, the wind was only from the SE for $1171 \mathrm{~h}$. Meteorological data from the Unified Model analyses are used to calculate the Pasquill-Gifford stability class. When applied in the Gaussian plume model, the monthly average $\mathrm{CH}_{4}$ emission for July is estimated at $616 \mathrm{~kg} \mathrm{~h}^{-1}$, in reasonable agreement with the estimates of 453 and $641 \mathrm{~kg} \mathrm{~h}^{-1}$ of the WindTrax inverse dispersion and Gaussian plume models using measured meteorological data. Emissions for all months are shown in Table 4.

In general, $\mathrm{CH}_{4}$ emission rates are higher during the winter months and lower during the summer months (Fig. 6). During the winter months (December, January, February) $\mathrm{CH}_{4}$ emission from the landfill is estimated at $1860 \mathrm{~kg} \mathrm{~h}^{-1}$ $\left(441 \mu \mathrm{g} \mathrm{m}^{-2} \mathrm{~s}^{-1}\right)$, whereas in the summer months (June, July, August) the $\mathrm{CH}_{4}$ emission drops more than half to $930 \mathrm{~kg} \mathrm{~h}^{-1}\left(207 \mu \mathrm{g} \mathrm{m}^{-2} \mathrm{~s}^{-1}\right)$. Variability in emissions is also larger in winter than in summer. The mean annual emission, calculated as the sum of the monthly mean emissions, is estimated at $11.6 \mathrm{Gg} \mathrm{yr}^{-1}$.

As before, scenarios were run using the GP approach to reflect variability in instrument precision, wind speed, temperature and the Pasquill-Gifford stability class (Table 5). Changing the temperature had no effect on the emission estimate, and instrument precision was a larger source of uncertainty, $\pm 9 \%$. However, the effect of instrument precision was smaller than the uncertainty in the case study, possibly because the measured mixing ratios are at their lowest during the summer. The calculation of the Pasquill-Gifford sta-

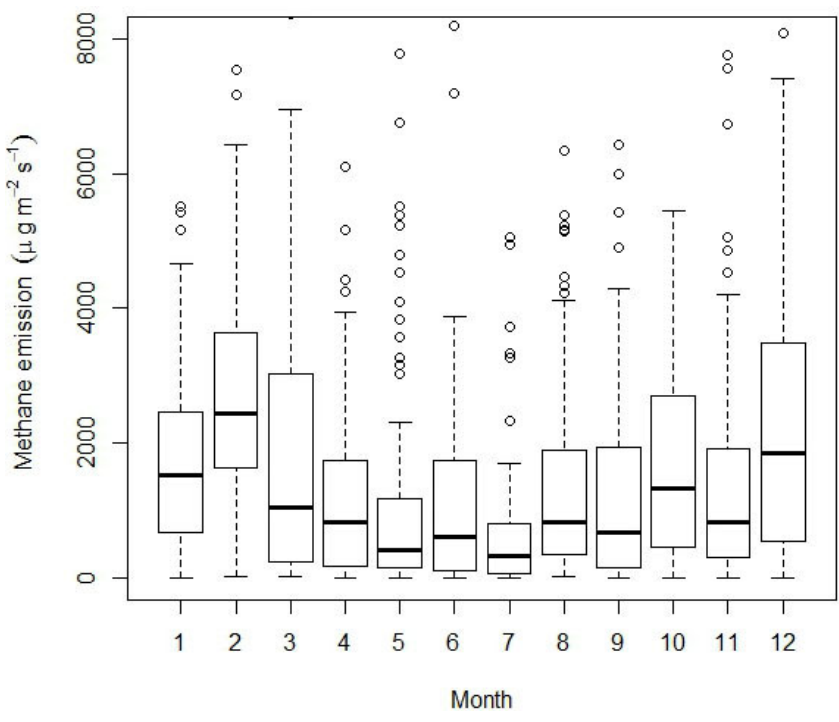

Figure 6. Box plot of hourly emissions calculated using the Gaussian plume modelling approach showing the monthly variability in methane emissions using data from 2012 to 2014.

bility class (PGSC) and the uncertainty in wind speed were the highest source of uncertainty, resulting in variability in $\mathrm{CH}_{4}$ emission of \pm 24 and $\pm 20 \%$, respectively. The overall uncertainty in $\mathrm{CH}_{4}$ emission is estimated to be $\pm 32 \%$.

\subsubsection{InTEM inversion model methane emission estimates}

The average annual $\mathrm{CH}_{4}$ emission from the landfill calculated using $\sim 24000$ hourly averaged $\mathrm{CH}_{4}$ mixing ratio data measured by the East Anglia network (Fig. 1) and NAME modelled meteorological data in the InTEM model is estimated at $13.7 \mathrm{Gg} \mathrm{yr}^{-1}$ (Table 4). The emission estimate was calculated from the average $\mathrm{CH}_{4}$ emission $19.9 \mu \mathrm{g} \mathrm{m}^{-2} \mathrm{~s}^{-1}$ calculated for an area of $2.17 \times 10^{7} \mathrm{~m}^{2}$. The standard deviation of the $\mathrm{CH}_{4}$ emission for 25 repeat runs of the InTEM model is $1.8 \times 10^{-5} \mathrm{~g} \mathrm{~s}^{-1} \mathrm{~m}^{-2}(91 \%)$. 
Table 3. Uncertainty analysis conducted on the case study (June 2015) for methane emission from the landfill at the Waterbeach Waste Management Park as calculated within the Gaussian plume modelling approach.

\begin{tabular}{lrrrr}
\hline Variable & Value used & $\begin{array}{r}\text { Average emission } \\
\left(\mu \mathrm{g} \mathrm{m}^{-2} \mathrm{~s}^{-1}\right)\end{array}$ & $\begin{array}{r}\text { Average emission } \\
\left(\mathrm{kg} \mathrm{h}^{-1}\right)\end{array}$ & $\begin{array}{r}\text { Uncertainty } \\
(\%)\end{array}$ \\
\hline Baseline & & 800 & 641 & \\
$\mathrm{CH}_{4}$ instrument precision & $\pm 0.5 \%$ & 973 & 781 & 22 \\
Wind speed measurement & $\pm 5 \%$ & 840 & 674 & 5 \\
Monin-Obukhov length & $\pm 7 \%$ & 800 & 641 & 0 \\
Temperature measurement & $\pm 5 \%$ & 795 & 638 & 0.4 \\
\hline
\end{tabular}

Table 4. Methane emission estimates from the landfill at the Waterbeach Waste Management Park as calculated by the WindTrax and Gaussian plume approaches for the case study (June 2015) and the annual estimates for the Gaussian plume and InTEM inversion modelling approach for 2012-2104.

\begin{tabular}{|c|c|c|c|c|}
\hline Month & $\begin{array}{r}\text { Case study } \\
\text { inverse dispersion } \\
\left(\mathrm{kg} \mathrm{h}^{-1}\right)\end{array}$ & $\begin{array}{l}\text { Annual estimate } \\
\text { Gaussian plume } \\
\qquad\left(\mathrm{kg} \mathrm{h}^{-1}\right)\end{array}$ & $\begin{array}{l}\text { Gaussian plume } \\
\qquad\left(\mathrm{kg} \mathrm{h}^{-1}\right)\end{array}$ & InTEM \\
\hline January & & & 1370 & \\
\hline February & & & 2160 & \\
\hline March & & & 1580 & \\
\hline April & & & 1110 & \\
\hline May & & & 830 & \\
\hline June & & & 1070 & \\
\hline July & $453 \pm 20 \%$ & $641 \pm 23 \%$ & 616 & \\
\hline August & & & 1100 & \\
\hline September & & & 1480 & \\
\hline October & & & 1350 & \\
\hline November & & & 1210 & \\
\hline \multirow[t]{2}{*}{ December } & & & 2040 & \\
\hline & & ission $\left(\mathrm{Gg} \mathrm{yr}^{-1}\right)$ & $11.6 \pm 32 \%$ & $13.7 \pm 91 \%$ \\
\hline
\end{tabular}

\section{Discussion and conclusions}

The data presented in this paper give the first comparison of methane emissions from a working landfill calculated using three models at different scales: (a) near source, $<1 \mathrm{~km}$ (WindTrax); mid-distance, 1-7 km (Gaussian plume); and far field, 7-70 km (InTEM). Near-source measurements were taken $300 \mathrm{~m}$ to the north-west of the Waterbeach Waste Management Park, Cambridgeshire, on 30 June and 1 July 2015. Mid-distance measurements were taken from Haddenham church, $7 \mathrm{~km}$ north-west of the landfill, between July 2012 and July 2015. Far-field measurements were taken throughout East Anglia, ranging from 7 to $100 \mathrm{~km}$ from the landfill, between July 2012 and July 2015.

After using ${ }^{13} \mathrm{CH}_{4}$ signatures to confirm that the source of the large $\mathrm{CH}_{4}$ mixing ratios is a nearby landfill, average $\mathrm{CH}_{4}$ emissions estimated using near-source measurements are $453 \mathrm{~kg} \mathrm{~h}^{-1}$ on 30 June and 1 July 2015 and agree within associated uncertainties when compared to the mid-distance emission estimates of $641 \mathrm{~kg} \mathrm{~h}^{-1}$. From the limited observa- tion period, we also observe greater variability in emissions using the near-source method, in accord with the findings of Riddick et al. (2016) that suggest that near-source estimates can be affected by the heterogeneous nature of the landfill. We suggest that the agreement in emissions estimates between the near-source and middle-distance methods indicates that a Gaussian plume approach can be used to estimate emissions up to $7 \mathrm{~km}$ from a relatively large source. However, this may be an upper estimate of the distance that this approach is effective at, as the fetch between the source and detector was relatively flat, and a more aerodynamically complex landscape may reduce the model's efficacy.

Using mid-distance measurements throughout the year, we estimate the annual $\mathrm{CH}_{4}$ emissions from the site to be $11.6 \mathrm{Gg} \mathrm{yr}^{-1}$ which is comparable to the $\mathrm{CH}_{4}$ emission estimate as calculated using the InTEM inversion method of $13.7 \mathrm{Gg} \mathrm{yr}^{-1}$. Our results suggest that larger emission hotspots can be detected within the emission landscape generated by an inversion model. However, we would suggest that future sensitivity studies should be conducted to estimate 
Table 5. Uncertainty analysis conducted on the annual methane emission from the landfill at the Waterbeach Waste Management Park as calculated within the Gaussian plume modelling approach.

\begin{tabular}{lrrrr}
\hline Variable & Value used & $\begin{array}{r}\text { Average emission } \\
\left(\mu \mathrm{g} \mathrm{m}^{-2} \mathrm{~s}^{-1}\right)\end{array}$ & $\begin{array}{r}\text { Average emission } \\
\left(\mathrm{kg} \mathrm{h}^{-1}\right)\end{array}$ & $\begin{array}{r}\text { Uncertainty } \\
(\%)\end{array}$ \\
\hline Baseline & & 1650 & 1320 & \\
$\mathrm{CH}_{4}$ Instrument Precision & $\pm 0.5 \%$ & 1790 & 1440 & 9 \\
Wind Speed Measurement & $\pm 20 \%$ & 1980 & 1590 & 20 \\
PGSC & $\pm 1 \mathrm{SC}$ & 1490 & 1200 & 24 \\
Temperature Measurement & $\pm 20 \%$ & 1640 & 1320 & 1 \\
\hline
\end{tabular}

the size of emission hot-spots within a landscape where the source is farther from a measurement site used as input to the inversion model.

The $\mathrm{CH}_{4}$ emissions from this landfill site are seasonal with the largest emissions during the winter months (February $2160 \mathrm{~kg} \mathrm{~h}^{-1}$ ) and the lowest emissions during the summer months $\left(616 \mathrm{~kg} \mathrm{~h}^{-1}\right)$. This may be linked to the seasonal cycle in environmental conditions as there is an inverse relationship between $\mathrm{CH}_{4}$ emission and temperature. The temperature relationship may be explained by the increased activity of methanotrophic bacteria in the top layers of landfill as the temperature increases.

The $\mathrm{CH}_{4}$ emissions from this landfill site are seasonal with the largest emissions during the winter, colder months (February: $2160 \mathrm{~kg} \mathrm{~h}^{-1}$ ) and the lowest emissions during the summer, warmer months $\left(616 \mathrm{~kg} \mathrm{~h}^{-1}\right)$. This is explained by the following mechanism (Borjesson and Svensson, 1997). The temperature within the landfill is relatively stable so that the sub-surface production of $\mathrm{CH}_{4}$ is roughly constant. In summer when the surface temperature is higher, the activity of methanotrophic bacteria in the top layers of landfill is enhanced, so that the net emission into the atmosphere is reduced. Our measurements are the first off-site measurements to demonstrate this and so are not susceptible to the sampling uncertainties associated with chamber techniques.

The $\mathrm{CH}_{4}$ emission estimate made by this study of $11.6 \mathrm{Gg} \mathrm{yr}^{-1}$ from this site is an important contribution to the waste component $\left(714 \mathrm{Gg} \mathrm{yr}^{-1}\right)$ of the 2014 total UK $\mathrm{CH}_{4}$ emission inventory (2157 $\mathrm{Gg} \mathrm{yr}^{-1}$; NAEI, 2016). We estimate the $11.6 \mathrm{Gg} \mathrm{yr}^{-1}$ emitted is produced from the $400 \mathrm{Gg}$ of total waste processed each year at the site (AMEY, 2016). The inferred $\mathrm{CH}_{4}$ emission to waste ratio at this site is lower (0.029) than the current UK ratio (0.045), where $1.0 \mathrm{Tg} \mathrm{CH}_{4} \mathrm{yr}^{-1}$ (EC-JRC/PBL, 2010) is emitted from $22 \mathrm{Tg}$ of solid waste disposed in landfill (Bergamaschi et al., 2015; UK Gov, 2016). This may be the result of differing environmental and management factors, such as differing mass fractions for each decomposing waste category (Jung et al., 2011), movement of landfill leachate (Attenborough et al., 2002) and site specific weather conditions (Maurice and Lagerkvist, 2004; Scheutz and Kjeldsen, 2004; Xu et al., 2014). Alternatively, $\mathrm{CH}_{4}$ emissions from new landfills which include a high component of recycling are currently overestimated.

Even though the annual emission estimate calculated using the InTEM inversion model is close to that calculated by the Gaussian plume model, the uncertainty associated with the InTEM inversion estimate is large. Comparison of the measurements with the $\mathrm{CH}_{4}$ time series produced by NAME InTEM (Supplement Figs. S1 and S2) shows the model to consistently underestimate the larger and sharper observed peaks. This arises as a result of the smaller weighting given to the peaks in the observed atmospheric concentrations in the NAME InTEM analysis (which uses all data) than in the WindTrax and Gaussian plume analyses which focus on these peaks. In particular, high peaks are underweighted because they are small-scale features not easily delineated in the regional inversions and the boundary layer is harder to model accurately at night when the highest peaks tend to occur due to their containment within the shallow nocturnal boundary layer. The heteroscedasticity seen in Supplement Fig. S2 is therefore to be expected as NAME InTEM reproduces the lower values better than the high ones.

The inherent challenges in inversion modelling, such as assuming a constant monthly emission (Supplement Sect. S2, Fig. S2.3) and the atmospheric variability at night which is poorly resolved by the model, result in the emission estimates calculated in this research having an uncertainty of $\pm 91 \%$. This research is presented as an example of inversion modelling: a work in progress and, while the emission estimates are currently uncertain, the location of the emissions are well represented.

The output from NAME InTEM inversion model shows that reasonably dense measurement networks can be used to identify emission hotspots within an emission landscape. Once potential hotspot emission sources have been identified, year-round measurements coupled to a relatively simple Gaussian plume model could be used to estimate the annual average and any seasonality in the $\mathrm{CH}_{4}$ emissions. As lower cost sensors become available, a cost-effective system to monitor point-source emissions should become available. 
Data availability. Data can be accessed from the following Centre for Environmental Data Analysis (CEDA) server: http://catalogue. ceda.ac.uk/uuid/9fb1936a4a434befb772c53f79259fe7.

\section{The Supplement related to this article is available online at https://doi.org/10.5194/acp-17-7839-2017-supplement.}

Competing interests. The authors declare that they have no conflict of interest.

Acknowledgements. This project was supported by the UK Natural Environment Research Council (NERC) through the Greenhouse gAs UK and Global Emissions (GAUGE) project on grant number NE/K002570/1. We also thank the Department of Environment, Farming and Rural Affairs and the Royal Society for seed funding and NERC for additional support through grants NE/G014655/1, NE/J006246/1 and a PhD studentship for Sarah Connors. Special thanks to the owners of Mitchell Hill Farm, Cottenham, and to Holy Trinity church, Haddenham, for allowing us to site our instruments on their land.

Edited by: Eliza Harris

Reviewed by: two anonymous referees

\section{References}

AMEY: Amey, Oxford, UK, available at: http://wasteservices. amey.co.uk/where-we-work/cambridgeshire/, last access: October 2016.

Attenborough, G. M., Hall, D. H., Gregory, R. G., and McGoochan, L.: Development of a landfill gas risk assessment model: GasSim, in: Proceedings for solid waste association of North America, 25 Annual Landfill Gas Symposium, Monterey, California, USA (March), 25-28, 2002.

Bergamaschi, P., Corazza, M., Karstens, U., Athanassiadou, M., Thompson, R. L., Pison, I., Manning, A. J., Bousquet, P., Segers, A., Vermeulen, A. T., Janssens-Maenhout, G., Schmidt, M., Ramonet, M., Meinhardt, F., Aalto, T., Haszpra, L., Moncrieff, J., Popa, M. E., Lowry, D., Steinbacher, M., Jordan, A., O'Doherty, S., Piacentino, S., and Dlugokencky, E.: Top-down estimates of European $\mathrm{CH}_{4}$ and $\mathrm{N}_{2} \mathrm{O}$ emissions based on four different inverse models, Atmos. Chem. Phys., 15, 715-736, https://doi.org/10.5194/acp-15-715-2015, 2015.

Borjesson, G. and Svensson, B. H.: Seasonal and diurnal methane emissions from a landfill and their regulation by methane oxidation, Waste Manage. Res., 15, 33-54, 1997.

Chen, Y.-H. and Prinn R. G.: Estimation of atmospheric methane emissions between 1996 and 2001 using a three-dimensional global chemical transport model, J. Geophys. Res., 111, D10307, https://doi.org/10.1029/2005JD006058, 2006.

Connors, S.: Development of a method for estimating methane gas emissions at high resolution, $\mathrm{PhD}$ thesis, University of Cambridge, 2015.
Connors, S., Manning, A. J., Robinson, A. D., Riddick, S. N., Harris, P. R., Forster, G., Oram, D., O’Doherty, S., and Skelton, R L.: Estimating methane emissions at high spatial resolution using the inversion technique InTEM - a proof of concept study, in preparation, 2017

Cullen, M. J. P.: The unified forecast/climate model, Meteor. Mag., 122, 81-94, 1993.

Dlugokencky, E. J., Myers, R. C., Lang, P. M., Masarie, K. A., Crotwell, A. M., Thoning, K. W., Hall, B. D., Elkins, J. W., and Steele, L. P.: Conversion of NOAA atmospheric dry air $\mathrm{CH}_{4}$ mole fractions to a gravimetrically prepared standard scale, J. Geophys. Res., 110, D18306, https://doi.org/10.1029/2005JD006035, 2005.

Dlugokencky, E. J., Nisbet, E. G., Fisher, R., and Lowry D.: Global atmospheric methane: budget, changes and dangers, Philos. T. Ser. A, 369, 205872, https://doi.org/10.1098/rsta.2010.0341, 2011.

EC-JRC/PBL: Emission Database for Global Atmospheric Research (EDGAR), release version 4.1., European Commission, Joint Research Centre (JRC)/Netherlands Environmental Assessment Agency (PBL)m 2010.

Fisher, R., Lowry, D., Wilkin, O. Sriskantharajah, S., and Nisbet, E. G.: High-precision, automated stable isotope analysis of atmospheric methane and carbon dioxide using continuous-flow isotope-ratio mass spectrometry, Rapid Commun. Mass Spectrom., 20, 200-208, https://doi.org/10.1002/rcm.2300, 2006.

Flesch, T. K., Wilson, J. D., and Yee, E.: Backward-time Lagrangian stochastic dispersion models, and their application to estimate gaseous emissions, J. Appl. Meteorol., 34, 1320-1332, 1995.

Flesch, T. K., Harper, L. A., Powell, J. M., and Wilson, J. D.: Inverse dispersion calculation of ammonia emissions from Wisconsin dairy farmsm Transactions of the American Society of Agricultural and Biological Engineers, 52, 253-265, 2009.

Flesch, T. K., Wilson, J. D., Harper, L. A., and Crenna, B. P.: Estimating gas emission from a farm using an inverse-dispersion technique, Atmos. Environ., 39, 4863-4874, 2005.

Flesch, T. K., Wilson, J. D., Harper, L. A., Crenna, B. P., and Sharpe, R. R.: Deducing ground-air emissions from observed trace gas mixing ratios: A field trial, J. Appl. Meteorol., 43, 487-502, 2004.

Google Earth 7.1.5.1557: Waterbeach Waste Management Park, $52.302 \mathrm{~N}, 0.180 \mathrm{E}$, elevation $14 \mathrm{~m}, 3 \mathrm{D}$ Buildings data layer, available at: http://www.google.com/earth/index.html (last access: 20 September 2016), 2015.

Hegde, U., Chang, T. C., and Yang, S. S.: Methane and carbon dioxide emissions from Shan-Chu-Ku landll site in northern Taiwan, Chemosphere, 52, 127585, https://doi.org/10.1016/S00456535(03)00352-7, 2003.

Hensen, A. and Scharff, H.: Methane Emission Estimates from Landfills Obtained with Dynamic Plume Measurements, Water Air Soil Pollut., 1, 455-464, 2001.

Hensen, A., Nemitz, E., Flynn, M. J., Blatter, A., Jones, S. K., Sørensen, L. L., Hensen, B., Pryor, S. C., Jensen, B., Otjes, R. P., Cobussen, J., Loubet, B., Erisman, J. W., Gallagher, M. W., Neftel, A., and Sutton, M. A.: Inter-comparison of ammonia fluxes obtained using the Relaxed Eddy Accumulation technique, Biogeosciences, 6, 2575-2588, https://doi.org/10.5194/bg-6-25752009, 2009. 
IPCC: Climate Change 2013: The Physical Science Basis. Contribution of Working Group I to the Fifth Assessment Report of the Intergovernmental Panel on Climate Change, edited by: Stocker, T. F., Qin, D., Plattner, G.-K., Tignor, M., Allen, S. K., Boschung, J., Nauels, A., Xia, Y., Bex, V., and Midgley, P. M., Cambridge University Press, Cambridge, United Kingdom and New York, NY, USA, 1535 pp., https://doi.org/10.1017/CBO9781107415324, 2013.

Jones, A., Thomson, D., Hort, M., and Devenish, B.: The U.K. Met Office's Next-Generation Atmospheric Dispersion Model, NAME III, in: Air Pollution Modeling and Its Application XVII, edited by: Borrego, C. and Norman, A.-L., 580-589, Springer US, https://doi.org/10.1007/978-0-387-68854-1_62, 2007.

Jung, Y., Imhoff, P., and Finsterle, S.: Estimation of Landfill Gas Generation Rate and Gas Permeability Field of Refuse Using Inverse Modeling, Transp. Porous. Med., 90, 41, https://doi.org/10.1007/s11242-010-9659-8, 2011.

Kirschke, S., Bousquet, P., Ciais, P., Saunois, M., Canadell, J. G., Dlugokencky, E. J., Bergamaschi, P., Bergmann, D., Blake, D. R., Bruhwiler, L., Cameron-Smith, P., Castaldi, S., Chevallier, F., Feng, L., Fraser, A., Heimann, M., Hodson, E. L., Houweling, S., Josse, B., Fraser, P. J., Krummel, P. B., Lamarque, J.F., Langenfelds, R. L., Le Quere, C., Naik, V., O’Doherty, S., Palmer, P. I., Pison, I., Plummer, D., Poulter, B., Prinn, R. G., Rigby, M., Ringeval, B., Santini, M., Schmidt, M., Shindell, D. T., Simpson, I. J., Spahni, R., Steele, L. P., Strode, S. A., Sudo, K., Szopa, S., Van Der Werf, G. R., Voulgarakis, A., Van Weele, M., Weiss, R. F., Williams, J. E., and Zeng, G. : Three decades of global methane sources and sinks, Nat. Geosci., 6, 813-823, https://doi.org/10.1038/ngeo1955, 2013.

Laubach, J., Kelliher, F. M., Knight, T. W., Clark, H., Molano, G., and Cavanagh, A.: Methane emissions from beef cattle - a comparison of paddock-and animal-scale measurements, Aust. J. Exp. Agr., 48, 132-137, 2008.

Manning, A. J.: Estimating European emissions of ozonedepleting and greenhouse gases using observations and a modeling back-attribution technique, J. Geophys. Res., 108, 4405, https://doi.org/10.1029/2002JD002312, 2003.

Manning, A. J., O'Doherty, S., Jones, A. R., Simmonds, P. G., and Derwent, R. G.: Estimating UK methane and nitrous oxide emis- sions from 1990 to 2007 using an inversion modeling approach, J. Geophys. Res., 116, D02305, https://doi.org/10.1029/2010JD014763, 2011.

Maurice, C. and Lagerkvist, A.: Assessment of the methane oxidation capacity of soil, Waste Manage. Res., 22, 42-48, 2004.

Mønster, J. G., Samuelsson, J., Kjeldsen, P., Rella, C. W., and Scheutz, C.: Quantifying methane emission from fugitive sources by combining tracer release and downwind measurements - a sensitivity analysis based on multiple field surveys, Waste Manage., 34, 1416-1428, 2014.

NAEI: National Atmospheric Emissions Inventory, Pollutant: Methane, available at: http://naei.defra.gov.uk/overview/ pollutants?pollutant_id=3, last access: October 2016.

Pan J., Yan X.-H., Jo Y.-H., Zheng Q., and Liu, W. T.: A new method for estimation of the sensible heat flux under unstable conditions using satellite vector winds, J. Phys. Oceanogr., 34, 968-977, https://doi.org/10.1175/15200485(2004)034<0968:ANMFEO>2.0.CO;2, 2004.
Pasquill, F.: Limitations and prospects in estimation of dispersion of pollution on a regional scale, Transactions-American Geophysical Union, 55, 144-144, 1974.

Paul, J. B., Lapson L., and Anderson J. G.: Ultrasensitive absorption spectroscopy with a high- finesse optical cavity and off-axis alignment, Appl. Optics, 40, 4904-4910, https://doi.org/10.1364/AO.40.004904, 2001.

Riddick, S. N., Hancock, B. R, Robinson, A. D., Connors, S., Davies, S., Allen, G., Pitt, J., and Harris, N. R. P.: Development of a low-maintenance measurement approach to continuously estimate methane emissions: A case study, Waste Management, ISSN 0956-053X, https://doi.org/10.1016/j.wasman.2016.12.006, 2016.

Saunois, M., Bousquet, P., Poulter, B., Peregon, A., Ciais, P., Canadell, J. G., Dlugokencky, E. J., Etiope, G., Bastviken, D., Houweling, S., Janssens-Maenhout, G., Tubiello, F. N., Castaldi, S., Jackson, R. B., Alexe, M., Arora, V. K., Beerling, D. J., Bergamaschi, P., Blake, D. R., Brailsford, G., Brovkin, V., Bruhwiler, L., Crevoisier, C., Crill, P., Covey, K., Curry, C., Frankenberg, C., Gedney, N., Höglund-Isaksson, L., Ishizawa, M., Ito, A., Joos, F. Kim, H.-S., Kleinen, T., Krummel, P., Lamarque, J.-F., Langenfelds, R., Locatelli, R., Machida, T., Maksyutov, S., McDonald, K. C., Marshall, J., Melton, J. R., Morino, I., Naik, V., O’Doherty, S., Parmentier, F.-J. W., Patra, P. K., Peng, C., Peng, S., Peters, G. P., Pison, I., Prigent, C., Prinn, R., Ramonet, M., Riley, W. J., Saito, M., Santini, M., Schroeder, R., Simpson, I. J., Spahni, R., Steele, P., Takizawa, A., Thornton, B. F., Tian, H., Tohjima, Y., Viovy, N., Voulgarakis, A., van Weele, M., van der Werf, G. R., Weiss, R., Wiedinmyer, C., Wilton, D. J., Wiltshire, A., Worthy, D., Wunch, D., Xu, X., Yoshida, Y., Zhang, B., Zhang, Z., and Zhu, Q.: The global methane budget 2000-2012, Earth Syst. Sci. Data, 8, 697-751, https://doi.org/10.5194/essd-8-697-2016, 2016.

Scheutz, C. and Kjeldsen, P.:Environmental factors influencing attenuation of methane and hydrochlorofluorocarbons in landfill cover soils, J. Environ. Qual., 33, 72-79, 2004.

Seinfeld, J. H. and Pandis, S. N.: Atmospheric Chemistry and Physics: From Air Pollution to Climate Change London, John Wiley \& Sons, 2006.

Themelis N. and Ulloa, P.: Methane generation in landfills, Renew. Energ., 32, 1243-1257, 2007.

UK Gov: UK Statistics on waste, available at: https: //www.gov.uk/government/uploads/system/uploads/attachment_ data/file/593040/UK_statsonwaste_statsnotice_Dec2016_ FINALv2_2.pdf, last access: October 2016.

$\mathrm{Xu}$, L., Lin, X., Amen, J., Welding, K., and McDermitt, D.: Impact of changes in barometric pressure on landfill methane emission, Global Biogeochem. Cy., 28, 679-695, https://doi.org/10.1002/2013GB004571, 2014.

Zannetti, P.: Air Pollution Modeling - Theories, Computational Methods, and Available Software, Computational Mechanics Publications, Southampton, and Van Nostrand Reinhold, New York, 450 pp., 1990.

Zazzeri, G., Lowry, D., Fisher, R. E., France, J. L., Lanoisellé, M., and Nisbet, E. G.: Plume mapping and isotopic characterisation of anthropogenic methane sources, Atmos. Environ., 110, 151162, https://doi.org/10.1016/j.atmosenv.2015.03.029, 2015. 